\title{
Kontraspionage, kultur og kontinuitet i Kreml: Et efterretningsteoretisk perspektiv på Ruslands interventioner i Ukraine
}

\section{Simone Gundtoft ${ }^{\star}$}

Cand.scient pol., løjtnant og sprogofficerskadet ved Forsvarsakademiet, København

\begin{abstract}
By applying the specialized terminology and theoretical approaches of the field of intelligence analysis, this article investigates Russian hybrid warfare in the case of Ukraine in order to offer a fuller understanding of this disputed phenomenon. Most scholars have addressed the concept of Russian hybrid warfare through a rather classical war-theoretical approach. This article, however, argues that any analysis of Russian warfare should take as its point of departure the extensive and historically consistent influence of the country's security services. The liberal analysis presented here reveals the prevailing continuity that characterizes Russian foreign policy, including the country's current actions in Ukraine. Most importantly, the liberal approach sheds light on the sources of this continuity, finding them embedded primarily within the security apparatus and its peculiar, strategic culture and mindset. This means that Russia's military actions are based on the assumption that the threat from the West is imminent, and on a fundamental focus on regime security. Russian warfare today is not the result of a new, coherent military doctrine or a belief in newfound superiority as proponents of the non-liberal approach often argue - instead, it is rather born out of fear.
\end{abstract}

Keywords: Russian foreign policy, hybrid warfare, intelligence studies, Ukraine, counterintelligence

\section{Indledning}

Analysen behandler spørgsmålet om, hvorledes de aktuelle, russiske aktiviteter i Ukraine, der for alvor begyndte i marts 2014 med annekteringen af Krim-halvøen, kan anskues $i$ et efterretningsteoretisk perspektiv, og hvordan et sådant alternativt perspektiv kan bidrage til en klarere forståelse af Ruslands udenrigspolitiske ageren og formåen. Hovedkonklusionen er, at de russiske militære aktiviteter i vidt omfang udspringer af efterretningstjenesternes betragtelige politiske indflydelse i landet,

\footnotetext{
^Kontaktinformasjon: Simone Gundtoft Simonsen. Email: sisi@s.fak.dk
} 
og dermed deres særegne kultur. Nutidig russisk krigsførelse, herunder Ukraineinterventionerne, har således samtidshistoriske rødder, og karakteriseres bedre som aktiv efterretningsvirksomhed frem for som udtryk for ren militær nytænkning.

Begrebet hybrid krigsførelse dukker ofte op i aktuelle sikkerhedspolitiske analyser, samt blandt organisationer og personer, der beskæftiger sig med krigsteori og militær strategi. Trods denne nye popularitet kan hybridkrig med rette betegnes som et både vagt og omstridt koncept, og der hersker stor uenighed om dets reelle praktiske anvendelighed (eksempelvis Reichborn-Kjennerud \& Cullen 2016). På et overordnet niveau refererer begrebet til, at grænserne mellem det militære og det civile - og mellem krig og fred - sløres og, at kampene udkæmpes både rent fysisk og i informationsrummet. Traditionelle militære virkemidler sammentænkes med ikke-militære, hvilket i yderste konsekvens kan betyde en krig uden egentlig konfrontation (Hansen 2016).

Fælles for størsteparten af den eksisterende forskning i hybridkrig er, at den anlægger en klassisk krigsteoretisk vinkel på begrebet, og blandt andet søger at indlemme det $\mathrm{i}$ den bredere akademiske debat om eksistensen af såkaldte "new wars" (eksempelvis Kaldor 1999; Hoffman 2007; Renz \& Smith 2016). I modsætning hertil argumenterer jeg for, at det for Ruslands vedkommende snarere er analytisk givtigt at diskutere hybridkrig i relation til efterretningsteori, og at dette kan højne forståelsen af - og bringe teoretisk såvel som empirisk klarhed over - russisk krigsførelse. Først og fremmest muliggør appliceringen af det efterretningsteoretiske felts specifikke terminologi en større indsigt i Ruslands adfærd ved at kortlægge kontinuiteten heri og i særdeleshed denne kontinuitets ophav; noget, som ikke er muligt med hybridkrigsbegrebet som det primære analyseværktøj. Ved at zoome ind på de russiske efterretningstjenesters rolle som selvstændige, udenrigspolitiske aktører tydeliggøres arven fra Sovjettiden, og hermed åbner analysen for en dybere forståelse af, hvordan russisk strategisk tænkning er formet, hvad denne tænkning består i, samt ikke mindst hvordan den påvirker landets udenrigspolitik. I særdeleshed bliver det muligt at studere indenrigspolitiske forhold i Rusland, herunder den interne rivalisering efterretningstjenesterne imellem. Alt dette kvalificerer ligeledes til et forsigtigt bud på, hvad vi kan forvente fra Kreml i den nærmeste fremtid. Ruslands nuværende militære engagement i Ukraine, der for alvor begyndte i marts 2014, betragtes i dag af mange eksperter som det klassiske eksempel på russisk hybridkrig og udgør derfor den centrale case hvorpå analysen er baseret.

\section{Metode og kildebrug}

Enhver analyse af hemmelige tjenesters adfærd og motiver er i sagens natur forbundet med en række begrænsninger, først og fremmest idet en stor del af efterretningstjenesternes aktiviteter netop er hemmelige, hvilket nødvendiggør visse forbehold. Ligeledes bør det understreges, at formålet med analysen 
af efterretningstjenesternes strategiske kultur og tankegang ikke er at påvise decideret kausalitet, men derimod at skabe en alternativ ramme, hvorigennem Ruslands udenrigspolitiske ageren kan forstås. Der er således først og fremmest tale om en sandsynliggørelse af en rekke sammenhenge, som har analytisk værdi, fordi den udfordrer den traditionelle opfattelse af Ruslands interventioner i Ukraine og ydermere leverer et konkret bud på, hvor kontinuiteten i russisk udenrigspolitik stammer fra.

Analysen baserer sig på en række forskellige kildetyper. ${ }^{1}$ Blandt primære kilder kan nævnes Mitrokhin-arkivet; en omfattende mængde KGB-filer indsamlet igennem en længere årrække af tidligere KGB-arkivar Vasilij Mitrokhin, og som efterfølgende blev gjort tilgængelige for offentligheden (Andrew \& Mitrokhin 2000). Ligeledes inddrages erindringer og udtalelser fra personer med efterretningsbaggrund, herunder ex-KGB-officer Igor Goloshchapov som præsenteret af Bateman (2014). Udfordringerne ved brugen af denne type kilder centrerer sig navnlig om to problemer: for det første er der en åbenlys risiko for bias og selektivitet, idet den tilgængelige datamængde er begrænset, hvilket mindsker muligheden for en systematisk kildeudvælgelse- og behandling. For det andet kan de pågældende afhoppere og ex-officerer have personlige motiver for udtalelserne, som kan resultere $i$ en vis skævvridning af det samlede billede. Alligevel vurderes disse kilder dog at udgøre et væsentligt bidrag til forståelsen af, hvorledes efterretningstjenesterne er indrettet, med det forbehold at der vil være nuancer og tendenser, som ikke afdækkes. Udfordringerne er blandt andet søgt overvundet ved at inddrage kilder, der historisk spænder vidt, for at kunne underbygge påstanden om kontinuitet eksempelvis før og efter Sovjetunionens sammenbrud.

Analysen baserer sig gennemgående på sekundærlitteratur og eksperters studier af efterretningsapparatets nutidige og historiske betydning. Heriblandt kan nævnes Erik Kulavigs (2007) kronologiske gennemgang af de russiske sikkerhedstjenesters struktur, rolle og virke "Fra Ivan den Grusomme til Vladimir Putin« baseret på blandt andet sovjetisk arkivmateriale; henholdsvis Tor Bukkvolls (2016) og Mark Galeottis $(2014 a ; 2014 b$; 2015; 2016) analyser af de russiske aktiviteter i Ukraine, herunder Galeottis fokus på den interne splittelse blandt efterretningstjenesterne, samt Maria Snegovayas (2015) studie af forandring og tilbagevendende elementer i russisk krigsførelse.

Særligt Galeottis bidrag anvendes hyppigt, og ud over de generelle forbehold er særligt spørgsmålet om, hvorvidt den militære tjeneste GRU er en primæraktør

\footnotetext{
${ }^{1}$ De anvendte kilder inkluderer: 1) primærkilder i form af arkivmateriale, erindringer og udtalelser fra relevante personer med efterretningsbaggrund; 2) diverse former for sekundær videnskabelig litteratur, i særdeleshed eksperters studier af det russiske efterretningsapparat og russisk politik, og teoretiseringer herover; 3 ) oversigtsgivende rapporter og analyser, herunder nøgletal fra FN, RUSI 2015-rapport om russiske styrker i Ukraine, samt officielle dokumenter publiceret af Kreml; 4) avisartikler og lignende onlinemateriale.
} 
i Ukraine, som Galeotti hævder, behæftet med en vis usikkerhed (se eksempelvis Galeotti 2014b; RUSI 2015; Bukkvoll 2016). Mark Galeotti er dog blandt de få, der systematisk har afdækket de russiske efterretningstjenesters selvstændige rolle i Ukraine, samt interne magtrelationers betydning i denne henseende. Denne sekundærkildebase indikerer netop, at en sådan vinkel på Ukraineinterventionerne er underbelyst, hvilken yderligere tilsiger min analyses relevans. Sammenholdt med de historiske kilder og arkivmaterialet beskrevet herover udgør Galeotti et fundamentalt bidrag, dog med visse forbehold i de afsluttende konklusioner.

Baseret på denne kildebase illustrerer jeg, hvordan man kan foretage en alternativ analyse af Ruslands interventioner i Ukraine i 2014 under inddragelse af efterretningsteori. Definitioner af blandt andet efterretning, kontraspionage, og af efterretningstjenesternes strategiske kultur appliceres empirisk, og der peges på flere elementer, som udfordrer den klassiske analyse af Ruslands såkaldt hybride krigsførelse. Disse indsigter hævdes, alt andet lige, og uagtet de udfordringer, der kan siges at være forbundet med det tilgængelige kildemateriale, at være af forskningsmæssig interesse.

Efter min indledende begrundelse for efterretningsteoriens relevans for problemstillingen, belyses det russiske sikkerhedsapparats udvikling i et historisk perspektiv. Herpå følger en uddybning af den kultur, de russiske efterretningstjenester repræsenterer, og hermed baggrunden for den måde, hvorpå de udøver indflydelse. Jeg konkluderer, at det er utilstrækkeligt blot at betragte Ukraine-interventionerne såvel som efterretningstjenesterne $u$ defra, hvilket er begrundelsen for at basere den øvrige analyse på den liberale forståelse af efterretningsvirksomhed for herigennem at belyse det komplekse samspil mellem de enkelte efterretningstjenester og andre kerneaktører. Denne model samt øvrige teoretiske antagelser præsenteres løbende.

\section{Hybridkrigsbegrebet og dets begrænsninger som analyseværktøj}

Den analytiker, der har været toneangivende i bestræbelsen på at definere hybridkrig som en konkret militær-operationel approach, er amerikanske Frank Hoffman, ifølge hvem vi i dag står over for et markant forandret og mere komplekst trusselsbillede i form af en "eskaleret konfliktdynamik». Der er ikke blot tale om, at antallet af traditionelle krige falder, men derimod en fusion af forskellige former for krig - regulære med irregulære, statslige med ikke-statslige - og derfor en sløring af grænserne herimellem samt mellem krig og fred i det hele taget (Hoffman 2007: 8). I tråd hermed beskriver Flemming Splidsboel Hansen, hvordan vidt forskellige militære og ikkemilitære virkemidler i dag koordineres, kombineres og synkroniseres for at opnå en synergieffekt: indsættelse af specialtropper, ikke-uniformerede og ordinære tropper, diplomati, cyber-angreb, økonomisk krigsførelse, brug af informationsteknologi og medier, samt støtte til bestemte (yderliggående) grupper (Hansen 2016: 3). En anden veteran på feltet, Mary Kaldor (1999), hævder, at nutidens krige er fundamentalt 
forskellige fra fortidens, både hvad angår metoder, finansiering og overordnede mål, hvilket afspejler, hvordan globaliseringen får statens voldsmonopol til at smuldre.

Som repræsentanter for den mere kritiske fløj konkluderer Renz og Smith (2016), at hybridkrig ikke er velegnet som analyseredskab til at belyse hverken Ruslands militære kapabiliteter eller politiske intentioner. De peger på risikoen for at overvurdere "det nye« i Ruslands krigsførelse, og således samtidig undervurdere dens kontinuitet. Ligeledes påpeger blandt andre Snegovaya (2015: 15) at ukonventionel krigsførelse altid har været en nødvendighed for Rusland som kompensation for en underlegen militær position, blandt andet teknologisk, sammenlignet med Vesten. I det følgende integrerer jeg løbende denne samt yderligere kritikker af hybridkrigsbegrebet, og peger på efterretningsteorien som alternativ analyseramme, og jeg placerer mig således i opposition til opfattelsen af, at russisk krigsførelse er udtryk for "ny krig" (jævnfør Kaldor 1999). Jeg skriver mig hermed ind i den bredere debat om, hvorvidt russisk hybridkrig er noget fundamentalt nyt. Mens mange sikkerhedspolitisk sagkyndige Ruslandseksperter allerede har konkluderet, at Ruslands udenrigspolitiske ageren afspejler kontinuitet snarere end forandring, ønsker jeg med hjælp fra det efterretningsteoretiske felt at gå skridtet videre. Jeg vil belyse, hvordan denne kontinuitet nærmere bestemt kan forstås: hvor stammer den fra, hvilke anskuelser ligger til grund for den - og hvad betyder det for, hvad vi kan forvente af Kreml? Jeg argumenterer for, at efterretningstjenesterne udgør kernen i disse spørgsmål, og at en analyse af russisk hybridkrig hverken kan eller bør isoleres fra sikkerhedsapparatets betydelige indflydelse i Rusland. Disse indsigter udgør denne analyses centrale bidrag.

\section{Efterretningsteoriens bidrag}

Ved efterretningsteori forstås overordnet det teoretiske apparat, der knytter sig til efterretningsbegrebet, herunder kontraspionage og aktive foranstaltninger; begreber, der uddybes undervejs i analysen. Ifølge Taylors (2010:300-301) definition omfatter efterretning den hemmelige indsamling, analyse og anvendelse af information om potentielt fjendtlige stater, grupper og individer, men samtidig også de konkrete aktiviteter, der har til formål at påvirke et andet lands politiske linje i det skjulte. Efterretninger kan bero på frit tilgængeligt såvel som hemmeligholdt materiale, og adskiller sig fra information ved deres mål: at muliggøre mere effektiv beslutningstagen, eksempelvis politisk eller militært (ibid.). Herunder skitseres argumentationen for, at en sådan efterretningsteoretisk analyseramme gør det muligt at overkomme nogle af hybridkrigsbegrebets begrænsninger, og herved kan øge forståelsen af russisk krigsførelse.

Den oplagte grund til, at det er relevant at belyse Ukraine-interventionerne gennem en efterretningsteoretisk linse er, at netop efterretningstienesterne, ifølge flere eksperter (Galeotti 2015 og 2016; Bukkvoll 2016; RUSI 2015), er blandt kerneaktørerne bag Ruslands aktiviteter i landet. Flere analytikere, herunder Bateman 
(2014), har desuden peget på, at dagens Rusland kan betegnes som en kontraspionagestat (counterintelligence state). Begrebet kontraspionagestat henviser til en stat med stærkt forvoksede og politisk autonome efterretningstjenester, hvis magt hviler på en bred og diffus forståelse af "sikkerhed" samt "indre og ydre fjender" (sammenlign Bateman 2014: 383). Denne begrebsbestemmelse indebærer, at vi bør studere efterretningstjenesternes virke og indflydelse for at forstå en stats udenrigspolitiske ageren. I særdeleshed det russiske sikkerhedsapparat indgår i en mangfoldighed af magtrelationer i et alt andet end entydigt forhold (se eksempelvis Kulavig 2007; Galeotti 2016), og netop denne komplekse magtstruktur udgør grundstenen i min analyse. Ved at fremhæve sikkerhedstjenesternes afgørende betydning tydeliggøres deres fejlbarlighed og indbyrdes konflikter. Denne metodiske indsigt leder frem til den liberale forståelse af efterretningsvirksomhed - et perspektiv, som savnes i traditionelle udlægninger af Ukraine-interventionerne, og hvor efterretningsteorien således leverer et særligt stort bidrag.

Jeg argumenterer i det følgende for, at Ruslands interventioner i Ukraine i et efterretningsteoretisk perspektiv er tæt knyttet til aktive foranstaltninger, altså handlingsdimensionen i Taylors udlægning af efterretningsbegrebet, som beskrevet ovenfor. Stan Taylor definerer konkret aktive foranstaltninger som "activities carried out by one state to alter political or economic developments in another state while disguising the source of that influence (Taylor 2010:311), og i modsætning til, hvad der gælder for informationsaspektet af efterretningsbegrebet, handler "covert action" således ikke om at skjule en given aktivitet, men derimod dens ophav (se også Stempel 2007: 125). Baseret på dette er det muligt at forstå de russiske interventioner i Ukraine som aktiv efterretningsvirksomhed, snarere end som udtryk for en ny militærdoktrin. Den indbyrdes relation mellem de russiske efterretningstjenester samt disses historiske udvikling belyses i de følgende afsnit.

\section{Det russiske sikkerhedsapparat i et historisk perspektiv}

I Sovjettiden opererede overordnet set to sikkerhedstjenester: GRU, Glavnoje Rasvedyvatelnoje Upravlenije, det Øverste Efterretningsdirektorat som varetog militær efterretning, og Komiteen for Statslig Sikkerhed, KGB, Komitet Gosudarstvennoj Besopasnosti (med navneskift undervejs), med ansvar for alt fra udenlandsspionage til indenrigssikkerhed. ${ }^{2}$ KGB var utvivlsomt den mest betydningsfulde af de to (se eksempelvis Galeotti 2016), hvorfor denne er hovedfokus for det følgende. Det bør dog bemærkes, at GRU, som blev grundlagt i 1950'erne, spillede en vigtig rolle blandt andet under krigene i Afghanistan (Bukkvoll 2016).

Generelt karakteriseredes Sovjettiden ved en klar arbejdsdeling mellem tjenesterne. KGB havde rødder i Tjekaen, det hemmelige politi, der oprettedes i 1917

${ }^{2}$ Se Bilag 1 for oversigt over anvendte forkortelser. 
som en væsentlig styrkelse af Lenins magtapparat, og i 1919 grundlagdes de første særlige afdelinger via sammenlægninger af den militære kontraspionage og Tjekaen (Kulavig 2007: 44). Alle oprør måtte nedkæmpes for at sikre regimets overlevelse, og Tjekaens specialtropper talte allerede i 1918 mere end 35 bataljoner. Mellem 1917-1921 henrettede organisationens folk omkring 250.000 mennesker (Kulavig 2007: 54). Tjekaen nedlagdes herefter på Lenins foranledning i 1921, og omdannedes til GPU, Gosudarstvennoje Polititjeskoje Upravlenije, dog uden fundamentale ændringer. Arbejdet intensiveredes i både udenlandske afdelinger og Afdelingen for Kontraspionage, og i årene 1921-24 arresteredes flere hundrede vestlige og japanske efterretningsfolk. I 1934 afløstes GPU af NKVD, Narodnyj Komissariat Vnutrennikh Del, Folkekommissariatet for Indre Anliggender, og trods reformer, der yderligere centraliserede magten hos Stalin, bestod kernefunktionerne (Kulavig 2007: 55-56). Igennem hele hans tid ved magten spillede sikkerhedstjenesten en afgørende rolle som Stalins personlige magtinstrument. NKVD skiftede i 1954, efter Stalins død, navn til KGB, men endnu en gang fastholdt organisationen sine grundpraksisser og øverste ledelse (Kulavig 2007: 75-78).

I 1950'erne og 1960'erne gennemførte KGB omfattende aktive foranstaltninger, herunder adskillige nynazistiske aktioner i Vesttyskland. KGB spillede desuden en nøglerolle i Kennedy-Krustjov-forhandlingerne under Cuba-krisen, og efterfølgende i afsættelsen af Krustjov (Kulavig 2007: 180-82). I 1960'erne opstod en adfærdsændring blandt KGB-agenterne, og arkivmateriale beskriver, hvordan de nye, unge agenter nu "var mere listige end brutale" (ibid.: 187-92). Trods den generelle lempelse i metoderne forblev KGB med Kulavigs (2007: 190) ord dog "alt for tilbøjelige til at se sammensværgelser", og i 1969 oprettedes Afdeling V, der specifikt varetog sabotage og likvideringer. Under Andropovs ledelse i årene 1967-82 fusioneredes KGB og Kommunistpartiet $i$ et sådant omfang, at det "var svært at sige, hvem der styrede hvem" (Kulavig 2007: 200). I 1970'erne voksede tjenestens spionnet, der allerede var verdens største, med yderligere 50 procent, så i 1985 rådede KGB over 400.000 agenter samt 200.000 meddelere. Gorbatjov ville stække KGB's magt, men var aldrig stærk nok til dette, og historikere er uenige om, hvorvidt han i det hele taget var vidende om de aktive foranstaltninger, KGB gennemførte i de sene 1980'ere (Kulavig 2007: 197-200).

\section{Efterretningstjenesterne efter Sovjetunionens sammenbrud}

Efter Sovjetunionens sammenbrud transformeredes KGB til (primært) FSB, Federalnaja Slusjba Besopasnosti, og SVR, Slusjba Vnesjnej Rasvedki, og gennemgik herved en opsplitning og modernisering frem mod Vladimir Putins indtrædelse som FSB-chef i 1998. Boris Jeltsin forsøgte i 1990'erne at reducere KGBs magt betydeligt, hvilket kun lykkedes delvist, blandt andet da han mødte modstand fra tidligere efterretningsofficerer - hvor FBI eksempelvis kun beskæftigede 24.000 mand i 1992, var der til sammenligning 150.000 ansatte i den russiske pendant (Kulavig 2007: 190-98). 
Under Putins præsidentperioder har sikkerhedsapparatet til fulde genvundet sin centrale placering i Rusland (Kulavig 2007: 200-220), hvilket underbygges i senere analyseafsnit. I modsætning til i Sovjettiden eksisterer der i dag et større antal efterretningstjenester med overlappende ansvarsområder, hvad angår eksempelvis kontraspionage og aktive foranstaltninger - et vigtigt strukturelt træk, som ligeledes belyses senere i analysen. De fire primære tjenester inkluderer den føderale tjeneste FSB, udenlandstjenesten SVR, den militære tjeneste GRU, samt FSO, Federalnaja Slusjba Okhrany, den føderale beskyttelsestjeneste (Galeotti 2016:2-4). Galeotti fremhæver SVR's arbejdsmetoder som traditionelle og baseret på KGB-arven, herunder dybe spionageringe og misinformationskampagner i stil med Sovjettidens. GRU's organisatoriske kultur har altid været kendetegnet ved risikovillighed, og tjenesten har en bred portefølje af ansvarsområder, herunder specialoperationer, politisk og økonomisk efterretning plus de berygtede »aktive foranstaltninger (Bukkvoll 2016: 18-19). Kerneopgaverne - intern og ekstern informationsindsamling, kontraspionage og aktive foranstaltninger, samt de dertil hørende arbejdsmetoder - opretholdes, om end de nu deles mellem flere sikkerhedstjenester.

\section{Efterretningstjenesterne som selvstændige, udenrigspolitiske aktører}

Jeg har nu påvist den påfaldende kontinuitet i det russiske sikkerhedsapparats roller og betydning. For at bringe analysen videre er det nødvendigt nu at specificere yderligere, hvad det er, der via sikkerhedstjenesterne har overlevet så længe, og som til stadighed påvirker russisk udenrigspolitik. Herunder kortlægges derfor den tænkning, de russiske efterretningstjenester konkret er repræsentanter for, og hermed baggrunden for den måde, hvorpå de udøver indflydelse. Jeg hævder, at denne tænkning såvel som dens ophav er blevet mistolket af nogle vestlige analytikere, hvilket hæmmer forståelsen af Ruslands adfærd og formåen. Denne påstand underbygges yderligere i det efterfølgende afsnit, hvor jeg præsenterer en alternativ udlægning af Ukraineinterventionerne som aktiv efterretningsvirksomhed. Dette belyses indledningsvis med udgangspunkt i efterretningstjenesternes strategiske kultur, og hermed antagelsen om, at kollektiv vanetænkning har selvstændig betydning for russisk udenrigspolitik. Strategisk kultur forstås konkret som "den vanetænkning og rygmarvsadfærd, der præger et lands sikkerhedspolitiske beslutningstagere» (Skak 2015: 2), hvilket er relateret til Taylors udlægning af efterretningstjenesterne som en kohorte, hvis medlemmers ens (efterretnings)baggrunde har resulteret i en fælles socialisering (Taylor 2011: 61-62).

Flere analytikere konkluderer, at de siloviki, "magtens mænd " med baggrund i efterretningsverdenen, sikkerhedsbranchen og militæret, der i Putins Rusland udgør en særdeles magtfuld gruppe, er bærere af en særegen strategisk kultur. Den er, ifølge blandt andre Soldatov og Borogan (2010a) samt Skak (2016), centreret omkring en 
stræben efter regimesikkerhed, som stammer fra den etik og tankegang, de som efterretningsofficerer blev skolet i. Galeotti (2016) spidsformulerer deres strategiske kultur som et "wartime mindset" - en krigsmentalitet, som aktivt opmuntres af Kreml. Selv før den igangværende forværring af forholdet til Vesten var det deres overbevisning, at Rusland står over for en eksistentiel trussel, der må imødegås gennem aktive, sommetider ekstreme, foranstaltninger. Eksempelvis udtalte Nikolaj Patrusjev, tidligere FSB-chef og nuværende sekretær i Sikkerhedsrådet, i 2015, "at USA ville foretrække, hvis Rusland som land slet ikke eksisterede" (Patrusjev 2015). Denne permanente krigsmentalitet består, ifølge Galeotti, konkret i tre hovedantagelser: 1) en nulsumstankegang om, at hvis Vesten taber, vinder Rusland, 2) Rusland trues direkte af Vestens forsøg på at gennemtvinge regimeskifte i skrøbelige stater og på at fastholde et amerikanskledet, vestligt globalt hegemoni, samt 3) handling overgår passivitet (Galeotti 2016).

I dette perspektiv bidrager krigsmentaliteten til at opretholde og ligefrem optrappe fjendskabet mellem Rusland og Vesten. Efterretningstjenesternes mænd er forenede gennem deres faste tro på et stærkt, centraliseret sikkerhedsapparat som samfundsbærende, og af missionen om at beskytte den russiske stat for enhver pris (eksempelvis Bateman 2014: 395). De besidder et fælles, anti-demokratisk verdenssyn, en opfattelse af Rusland som en global stormagt, samt loyalitet over for regimet og hinanden (Taylor 2011: 62). Blandt andet tidligere højtstående KGB-officer Igor Goloshchapovs beskrivelse af tiden efter Sovjetunionens kollaps illustrerer, hvor indflydelses- og omfangsrigt et netværk, det russiske efterretningsvæsen udgør, samt hvordan dets kerneværdier består:

(...) we had one objective: to survive and preserve our skills. We did not consider ourselves to be separate from those who stayed in the FSB. We shared everything with them and we saw our work as just another way of serving the interests of the state (Bateman 2014: 390-91).

I 2013 forfattede Generalstabschefen for de russiske væbnede styrker, Valerij Gerasimov, en omdiskuteret artikel, hvori han udpenslede den øgede betydning af ukonventionelle virkemidler i nutidig krigsførelse og manede til militær nytænkning fra russisk side. Artiklen blev kendt som Gerasimov-doktrinen, og den har affødt mange fortolkninger. Gerasimovs indlæg anses af mange vestlige analytikere for indvarslingen af en ny, russisk militærdoktrin baseret på hybrid krigsførelse, idet Ukraine-interventionerne anskues som virkeliggørelsen af den (Galeotti 2014a, 2015; McDermott 2016). En sådan tolkning hviler imidlertid ikke på russisk militærstrategisk tænkning som sådan, men primært på vestlige perceptioner og udlægninger af russisk udenrigspolitik (McDermott 2016; Skak 2016), og Cordesman (2014) pointerer, at det rummer en fare for at mistolke Ruslands intentioner såvel som kapabiliteter. Jeg argumenterer for, at min efterretningsteoretiske vinkel kan tilføre analytisk klarhed ved at stille skarpt på Ruslands egen opfattelse og håndtering af den sikkerhedspolitiske situation, idet min tilgang 
netop er funderet i de russiske efterretningstjenesters verdensbillede. Dette perspektiv, herunder eksempler på, hvordan krigsmentaliteten udmønter sig i praksis, præsenteres i afsnittet herunder.

\section{De russiske interventioner i Ukraine som aktiv kontraspionage}

I det følgende præsenteres argumenterne for, at Ukraine-interventionerne bør anskues som en del af den russiske kontraspionage-indsats snarere end som udtryk for en ny militærdoktrin. Kontraspionage refererer til de tiltag, en stat gennemfører med henblik på at gardere sig mod spionage, og er en lige så systematisk aktivitet som spionagen selv. Teoretisk kan begrebet knyttes til Gourevitchs (1978: 882) beskrivelse af, hvorledes udenrigspolitiske og globale forhold påvirker den indenrigspolitiske situation, idet kontraspionage særligt handler om at begrænse udefrakommende påvirkninger, og forhindre, at eksterne magter får held til at skabe intern opstand.

Relevante i den forbindelse er de såkaldte farverevolutioner, der dækker over et ikke-voldeligt magtskifte, som i den russiske debat imidlertid ses som faciliteret af en ekstern magt gennem påvirkning af protestpotentialet i befolkningen. Et centralt eksempel er Maidan-opstanden i Ukraine i 2013-2014, som i visse russiske kredse (efterretningsvæsenet i særdeleshed) anses for at være et resultat af vestlige fordækte manøvrer med folkestemningen - konkret CIA. Præsident Putin udtalte i kølvandet herpå, at "alt må sættes ind på at sikre, at noget lignende aldrig sker i Rusland (Putin 2014b) ligesom nyere russiske nationale sikkerhedsstrategier udtrykker samme anskuelser (Strategija Natsionalnoj Besopasnosti 2015). Ukraine-interventionerne rummer hermed andet end neorealismens ydre balanceringslogik, ifølge hvilken det er afgørende for Kreml at begrænse Vestens geopolitiske fremfærd. Der er samtidig tale om en indre balanceringslogik, ifølge hvilken det er en lige så høj prioritet at kontrollere interne uroligheder (hvor Vesten tillægges en nøglerolle), idet begge dele er afgørende for russisk regimesikkerhed. Ukraine-interventionerne bør hermed også anskues som et forsøg på at undgå indenrigspolitisk modstand mod Kremls greb om magten, og denne russiske logik leder netop tankerne hen på Peter Gourevitchs beskrivelse af kontraspionage (1978; se også Skak 2016).

Der er ganske vist en åbenlys russisk interesse i at hævde, at det var Vesten der "slog først", og at Rusland med Ukraine-interventionerne - sin kontraspionage - blot beskytter nationale interesser (Giles 2016). Hvem der i første omgang optrappede konfliktniveauet er dog ikke afgørende, for under alle omstændigheder viser Patrusjevs og Putins udtalelser, at interventionerne i Ukraine kobles til Vestens såkaldte destabilisering af verden. Fra russisk side fremstilles og håndteres sagen som en efterretningskrig - Rusland gengælder, hvad man betragter som Vestens aktive foranstaltninger med lige så aktiv kontraspionage. Således 
beskriver Stephen Blank hvordan den indenrigs- og udenrigspolitiske dimension i Ruslands sikkerhedspolitik set med russiske øjne er en reaktion på proaktiv, vestlig efterretningsvirksomhed:

[the Russian Government's] rhetoric of being a besieged fortress and the enduring argument that reformers at home are enemies linked with Western governments and intelligence agencies ensures the continuation of the Leninist threat paradigm linking both sets of enemies together and freezing the regime in an a priori hostility towards the West (Stephen Blank 2012: 103).

Ved en efterretningskrig forstås i praksis, at efterretningstjenesterne fungerer som primæraktører i en konflikt, der i vidt omfang udkæmpes på deres præmisser, hvilket jeg nu vil sandsynliggøre er tilfældet i Ukraine. Som indledningsvis beskrevet har særligt GRU ifølge Galeotti (2016) indtaget en nøglerolle, og adskillige analytikere har peget på, at de russiske undercover-soldater, som deltog $\mathrm{i}$ annekteringen af Krim, udgør en parallel til de virkemidler, de aktive foranstaltninger, KGB i sin tid anvendte (eksempelvis Snegovaya 2015). Disse arbejdsmetoder involverede ligeledes desinformationskampagner, propaganda og politisk repression - alt sammen kendetegnende for Ruslands aktuelle engagement i Ukraine, herunder de "små grønne mænd", russiske soldater og medlemmer af efterretningstjenesterne uden gradstegn, der blev indsat for indledningsvis at kunne benægte russisk tilstedeværelse i landet, og forsinke den internationale reaktion på interventionerne (Snegovaya 2015; Galeotti 2015; Bukkvoll 2016). Disse aktiviteter befinder sig ligesom efterretningsverdenens aktive foranstaltninger, i gråzonen mellem diplomati og krig (Stempel 2007; Giles 2016), og følgelig giver det mening at opfatte dem som netop aktive foranstaltninger.

Det statsejede TV-selskab Russia Today har ydermere været et redskab i tiltagene for at fremme Kremls mærkesager, herunder at underminere vestlige medier ved hjælp af, hvad Galeotti (2015) betegner som "a glitzy mix of genuine investigation, bizarre conspiracy theory, and cynical disingenuousness". Også Poulsen (2014) understreger sådanne paralleller til Sovjettiden, og beskriver, hvordan de sovjetiske sikkerhedstjenester under den Kolde Krig benyttede advarsler mod neonazisme som propagandaværktøj. Dokumenter fra de sovjetiske arkiver blev med jævne mellemrum manipuleret, blandt andet for at miskreditere politiske personligheder, herunder den tyske politiker Theodor Oberlander og general Adolf Heusinger, mod hvem der blev ført "vel- og centralt koordinerede kampagner, som mixede etablerede fakta med udokumenterede og decideret falske påstande" (Poulsen 2014: 4). Ligeledes blev nogle lettiske immigranter i USA i et sovjetisk forsøg på miskreditering udhængt som "neo-nazister i forklædning". Samme nazi-retorik har været anvendt $\mathrm{i}$ forbindelse med annekteringen af Krim, idet det russiske Udenrigsministerium i juli 2014 mente at vide, at "der i Ukraine pågår omfattende forbrydelser mod menneskeheden, begået af ultra-traditionalistiske og neo-nazistiske bevægelser» (Poulsen 2014: 4-5). 
Pointen i alt dette er, at det i høj grad er de russiske efterretningstjenester, der opretholder den historiske kontinuitet i russisk udenrigspolitik som følge af deres krigsmentalitet. Eller med Blanks formulering: Kremls fastlåsning i et »leninistisk trusselsparadigme« og et »a priori-fjendskab« over for Vesten. Følgelig er der belæg for at hævde, at det ikke mindst er efterretningstjenesternes strategiske og operative kultur, der afspejles i russisk udenrigspolitik, nu som under Sovjettiden. Ukraine-interventionerne markerer næppe nogen ny militærdoktrin, men er snarere udtryk for efterretningstjenesternes kontinuerlige stræben efter regimesikkerhed indadtil som udadtil. Ruslands udenrigspolitik udspringer af efterretningstjenesternes bestræbelser på at opnå regimesikkerhed, af idéen om truslen fra Vesten, samt tesen om, at handling overgår passivitet. Det er disse mentale logikker, der danner grundlag for de russiske handlinger i Ukraine (Bateman 2014; Sherr 2013). Vejen til regimesikkerhed er ikke én specifik - eller ny - strategi, men bygger på case-specifikke analyser af det operationelle miljø, og indebærer en kombination af mange forskellige, ikke altid koordinerede, virkemidler, samt dertil en god portion improvisation (McDermott 2016: 104-105). Netop derfor kan det konkrete forløb i Ukraine ikke uden videre overføres til andre kontekster.

\section{Frygt i praksis}

Analysen ovenfor indikerer ydermere, at efterretningstjenesternes krigsmentalitet udmønter sig i praksis som en til tider stærk frygt i forholdet til Vesten. I de perioder, hvor efterretningstjenesterne har spillet en særligt central, politisk rolle, har denne frygt derfor været særligt fremtrædende (Bateman 2014; Skak 2016). Vladimir Putin og Jurij Andropov, KGB-chef i 1960'erne og senere generalsekretær i det kommunistiske parti, er begge illustrative cases herpå, og derfor samtidig eksempler på, hvordan efterretningstjenesternes strategiske kultur konkret påvirker de politiske beslutningstagere. Eksistensen af denne frygt har ydermere konsekvenser for, hvad Vesten kan forvente af Kreml, hvilket diskuteres i senere afsnit.

Andropov var som generalsekretær særdeles optaget af forestillingen om, at CIA gennemførte aktiv spionagevirksomhed mod Rusland, og mod KGB-officerer og sovjetiske statsborgere i udlandet, og ville for enhver pris imødegå denne trussel, i særdeleshed gennem aktive foranstaltninger (Andrew \& Mitrokhin 2000: 494-495; Skak 2016). KGB-kulturen influerede gennemgående Andropovs politiske karriere, og hans efterfølger, Mikhail Gorbatjov, beskrev i sine memoirer, at »årene hos KGB havde sat tydelige spor på Andropovs holdninger, og evne til at træffe beslutninger, og havde forvandlet ham til en mistænksom mand, dedikeret til at beskytte regimet" (Pringle 2000: 201). Vladimir Putin har på tilsvarende vis været præget af sin baggrund som efterretningsofficer og FSB-chef, og har som præsident omgivet sig med tidligere efterretningsfolk, som han har placeret på topposter i den statslige administration, herunder Nikolaj Patrusjev og Viktor Tjerkesov - begge Putins gamle bekendte fra Sikkerhedstjenesten (Kulavig 2007; Soldatov \& Borogan 2010b). 
I Putins præsidentperiode er der ydermere foregået en bevægelse fra sikkerhedsliggørelse og til egentlig militarisering af farverevolutioner som retorisk fænomen. Med dette menes, at opfattelsen af, at disse er udtryk for ikke-militær krigsførelse, aktive foranstaltninger fra Vestens side, er blevet udbredt (Bouchet 2016). Ganske som Andropov anser Putin vestlig spionage og efterretningsvirksomhed for at være blandt de mest substantielle trusler mod Rusland (eksempelvis Putin 2014a), og har aktivt har søgt at minimere denne trussel. Ifølge Pringle har Putin ligefrem "igangsat en jagt på fjender, spioner og sabotører af Andropovske dimensioner" (2001: 548). Der er således klare fællestræk mellem Andropovs kontraspionage-nation, og Rusland underVladimir Putin, i det efterretningstjenesterne i begge tilfælde tillægges en bærende og aktiv rolle. Også Soldatov og Borogan (2010b: 69-71) beskriver disse ligheder mellem Putin og Andropov, herunder hvordan Putin aktivt har inkorporeret fortællinger om Andropov-tiden i sine forsøg på at højne sikkerhedstjenesternes anseelse efter Sovjetunionens sammenbrud.

Dette ses tydeligt afspejlet i Kremls nuværende farverevolutions-narrativ, hvor store dele af ustabilitet i Verden, som beskrevet, anskues som konsekvenser af vestlig efterretningsvirksomhed. I sin tale umiddelbart efter annekteringen af Krim beskrev Putin, hvordan den ene farverevolution direkte fører til den anden, ganske som dominobrikker, der falder på række. Alle er de forbundne, det Arabiske Forår såvel som opstandene i Ukraine og Georgien, og alle som én er de faciliteret af Vesten (Putin 2014a; Dreyfuss 2014). Trods utallige forsøg på konstruktiv dialog fra russisk side harVesten i Putins optik ikke udvist samarbejdsvilje, men tværtimod praktiseret en fortsat inddæmningspolitik og kontinuerlige forsøg på at holde Rusland nede (Putin 2014a). Selvom frygten for farverevolutioner er knyttet til nyere begivenheder, er den underliggende frygt således $i$ sin essens den samme som i Andropovs tid. Den næres af efterretningstjenesternes mentalitet, og deres syn på Vesten som en vedvarende trussel. Denne mentale logik betyder, at Ruslands engagement i Ukraine i højere grad skal tolkes som bundet i frygt, end som en russisk tro på overlegenhed (se også Cordesman 2014).Yderligere kan jagten på regimesikkerhed ligefrem tænkes at få selvødelæggende konsekvenser.

Særligt et perspektiv synes nu nødvendigt at forfølge yderligere. Det står klart, at det indenrigspolitiske element udgør en væsentlig faktor i forståelsen af de russiske aktiviteter, der langtfra kun rummer en ydre balanceringslogik, hvorfor det er utilstrækkeligt at anskue Ukraine-interventionerne, og sikkerhedsapparatet som aktør, udefra. Jeg argumenterer for, at en af efterretningsteoriens største forcer findes netop her, i form af den såkaldte liberale efterretningsmodel. Dette perspektiv uddybes nu.

\section{Den liberale efterretningsmodel: Hvad der gik godt på Krim - og galt i Donbas}

Som beskrevet ovenfor, har Ruslands militære engagement i Ukraine i denne analyse hidtil været behandlet som én, samlet case. Det er dog centralt at fastholde, at der 
er afgørende forskelle i, hvordan interventionerne henholdsvis på Krim-halvøen og i Donbas-regionen udspillede sig. Mens annekteringen af Krim forløb glat, nærmest uden tab af menneskeliv, er det samme langtfra tilfældet for den efterfølgende intervention i Donbas, der har udviklet sig til en udmattelseskrig, der har stået på i over 3 år (Freedman 2015). Ifølge FN-tal fra maj 2017 er mindst 10.000 døde, herunder over 2500 civile, og omkring 24.000 er sårede. Over 1,6 millioner er drevet på flugt, mens 3 millioner civile fortsat befinder sig i områder under militante gruppers kontrol. Der forekommer utallige brud på våbenhvilen og lejlighedsvise optrapninger af fjendtlighederne (OHCHR 2017).

Disse forskelle kan den liberale tilgang til efterretningsanalyse bidrage til at forklare, ligesom denne tilgang åbner for, at analysen kan bevæge sig ud over forestillingen om efterretningstjenesterne som en enhedsaktør. Den liberale analysemodel foreskriver grundlæggende, at vi skal studere indenrigspolitiske forhold, idet staten ikke opfattes som en enkelt, tæt sammensvejset og rationelt handlende enhed, men derimod som en splittet størrelse præget af interne uoverensstemmelser (Richards 2010: 9-12). Fokus er på efterretningsfejl, fordi efterretningsprocessen rummer utallige faldgruber. Dette problem anskueliggøres i efterretningsverdenen med en model kaldet efterretningskredsløbet; fem grundfaser, hvorigennem informationsindsamlingen og-behandlingen sker. Første fase udspringer af et behov for efterretninger, og herudfra planlægges dataindhentningen, der udgør anden fase. Herefter bearbejdes data, eksempelvis ved at sammenholde informationer fra forskellige kilder. Dette muliggør fortolkning af data, fjerde fase, som afslutningsvis udmunder i en reaktion. Denne reaktion kan antage enhver form; skriftlig, militær - eller ingenting (Hughes-Wilson 2004).

Ifølge Betts (1978) er efterretningsfejl oftere psykologiske, politiske og bureaukratiske end begrundet i mangelfuld information, og en konsekvens heraf er, at sådanne fejl er uundgåelige. I lighed med beskrivelsen ovenfor anskuer Betts efterretningsprocessen som en lang kæde, og når ét led styrkes, vil et andet blot knække (Betts 1978: 61-65). Eksempelvis vil politiske beslutningstagere, mere eller mindre bevidst, bearbejde de oplysninger, de modtager, med en bias i retning af egne præferencer, og det datamateriale de har til rådighed, er af natur altid åbent for fortolkning. Ligeledes kan efterretningsagenterne have egne præferencer, være ineffektive bureaukrater, eller ganske enkelt misforstå hvad der ønskes af dem. Der findes talrige historiske eksempler såsom Operation Barbarossa i 1941, hvor Stalin valgte at ignorere adskillige, indbyrdes uafhængige efterretninger om det forestående tyske angreb. Hans personlige ønske om at købe sig tid og forblive ved magten spillede ifølge nogle fortolkninger ind i den efterfølgende katastrofe for Sovjetunionen. Andre skoleeksempler er Falklands-invasionen i 1982, samt angrebet på World Trade Center (Hughes-Wilson 2004).

Ifølge både Galeotti (2016) og Bukkvoll (2016) ligger efterretningstjenesterne i dagens Rusland i skarp indbyrdes rivalisering grundet overlappende ansvarsområder. De kæmper blandt andet om Putins gunst, og søger hver især at fremstå 
som den stærkeste spiller, og det russiske efterretningsapparat er følgelig stærkt fragmenteret, og forfølger ikke udelukkende de fælles målsætninger. Dette kobler logisk til Taylors (2011: 64) udlægning af efterretningstjenesterne som dels klaner; adskilte enheder i intern konkurrence, dels korporationer; politisk-bureaukratiske aktører, der handler på magt og ressourcer snarere end overbevisninger. Loyaliteten blandt efterretningstjenesternes mænd overskygges ikke sjældent af egennyttemaksimerende hensyn, og den liberale tilgang er således indlysende relevant.

\section{Efterretningsfejl og intern rivalisering}

Ifølge Galeotti (2016) er Ukraine kerne-eksemplet på denne interne rivalisering. Som han beskriver den komplekse, russiske involvering: "(...) in 2014, the Foreign Intelligence Service operated there as if it was a foreign country, but so did the FSB, as if it was not. The GRU had penetrated Ukraine's security structures and was deeply embedded in Crimea" (Galeotti 2016: 4; se også RUSI 2015). Bukkvoll (2016) påpeger ligeledes GRU's aktive rolle i Ukraine, herunder i særdeleshed i Donbas, hvor meget tyder på, at tjenestens brigader har været involveret i såvel aktive foranstaltninger som direkte kamp. Også FSB har øjensynligt været dybt involveret i Donbas, og de enkelte tjenester er ifølge Bukkvoll hverken "villige eller i stand til at koordinere deres indsatser" (Bukkvoll 2016:21).

Det internationale samfund har ikke set med milde øjne på Ruslands militære tilstedeværelse i Donbas-regionen, og Kiev har udvist en GRU-oberstløjtnant, der arbejdede som attaché på den russiske ambassade i forlængelse af interventionerne, ligesom GRU's øverste chef, generalløjtnant Igor Sergun, figurerede på EU's seneste sanktionsliste (Galeotti 2014b). Umiddelbart synes en sådan negativ omtale problematisk for GRU, men ikke ifølge Galeotti (2014b), der ligefrem kalder krigen for "perverst god" for den militære tjeneste. Eftersom GRU i forvejen var nedskæringstruet og i fare for at blive udkonkurreret af FSB, har det været særdeles fordelagtigt for Ruslands militære efterretningstjeneste at spille en aktiv rolle i Ukraine (se også Bukkvoll 2016). Som Galeotti (2016) udtrykker det: "being 'persecuted' by Kyiv and Europe is a mark of pride in Putin's new Russia, and it is as good as a medal«. Med Galeottis ord er dårlig omtale i Putins Rusland bedre end ingen, så længe det bidrager til at fremstille Rusland som en stærk, international spiller, og meget peger ifølge ham på, at præsidenten er tilfreds med GRU's hidtidige indsats, blandt andet idet tjenesten efterfølgende ikke er blevet udsat for yderligere omfattende budgetnedskæringer. Tilstedeværelsen i Ukraine beskytter hermed GRU ved at sikre fortsat finansiering og begrænse rivaliseringen internt i efterretningsapparatet, og mindsker den trussel, som FSB udgør mod GRU. Det er kort sagt et spørgsmål om at gøre sig uundværlig, undgå nedskæringer, og i yderste konsekvens afvikling, også selvom dette medfører international sanktionering (Galeotti 2016).

Ifølge Galeotti (2015) opstod der i kølvandet på den vellykkede annektering af Krim, hvad han beskriver som en "cocky attitude" i Kreml. De efterfølgende 
Donbas-interventioner kan hermed anskues som én, stor efterretningsfejl opstået som følge af netop de psykologiske og politiske faldgruber, som Betts beskriver. Dels har beslutningstagerne i Kreml været berusede af den militære succes på Krim-halvøen, og derfor haft mod på at udvide offensiven, dels har GRU haft stærke incitamenter til at fortsætte indsatsen for at bevise sit værd og sin eksistensberettigelse. Det bør bemærkes, at det i sagens natur ikke er muligt at få indsigt i de konkrete beslutningsprocesser, der ligger til grund for forløbet. Trods dette vurderes Galeottis fortolkning af begivenhederne og de bagvedliggende, politiske motiver, på baggrund af den præsenterede teori og empiri, at være plausibel.

Slutteligt er forskellene mellem Krim og Donbas-interventionerne relateret til endnu en central kritik af hybridskrigsbegrebet: hybrid krigsførelse kan både dække over strategier, der søger henholdsvis at forkorte og forlænge konflikter. Den såkaldte hybridkrig på Krim forløb hurtigt, mens Donbas-interventionerne som beskrevet udviklede sig til en udmattelseskrig, hvilket gør det svært at operationalisere begrebet i praksis, da det er umuligt at definere klare succeskriterier (se også Renz \& Smith 2016). Hermed illustrerer forskellene på Ukraine-interventionerne i sig selv nødvendigheden af at belyse efterretningstjenesternes interne relationer og rolle som selvstændige, udenrigspolitiske aktører. Dette er nødvendigt for at forstå, hvorfor den tilsyneladende samme strategi kan få så forskellige udfald, som det har været tilfældet i Ukraine. Dette rummer hybridkrigsbegrebet i sig selv ingen forklaring på.

\section{Og hvad så? Om konsekvenserne for Vesten}

Denne analyse har kortlagt en overvejende kontinuitet i russisk udenrigspolitik, men der skal ikke herske tvivl om, at meget er forandret siden Sovjettiden. Som Kulavig (2007) påpeger, kan man ikke uden videre sidestille Sovjettidens og nutidens russiske efterretningstjenester. Forholdet mellem staten og sikkerhedsapparatet er fundamentalt anderledes end under det totalitære staten. Alligevel er parallellerne klare, og efterretningstjenesterne er til stadighed aktive, selvstændigt handlende instrumenter, der indgår i en pragmatisk, politisk symbiose med magthaverne, baseret på "(...) a shared perception of Russia's situation and goals" (Galeotti 2016: 6), og som på baggrund heraf håndterer trusler udefra såvel som indefra.

Ydermere har senere års teknologiske udvikling udvidet mulighederne for at føre ikke-lineær krig. Heriblandt kan nævnes opblomstringen af sociale medier, og de forbedrede muligheder for uden store omkostninger at gennemføre desinformationskampagner, sådan som Rusland gjorde i Ukraine. Ruslands krigsførelse er med andre ord tilpasset en moderne kontekst, og Snegovaya anfører, at »(...) contemporary Russia's information warfare mixes previous Soviet military disinformation tactics and analysis of the "American" information strategies with some constituent elements of the contemporary information environment" (2015: 13). Verden er ikke statisk, men omvendt går det ikke an ureflekteret at tolke Ruslands Ukraine-metoder som udtryk for en ny, russisk militærdoktrin (se eksempelvis Renz \& Smith 2016). 
Det underliggende ræsonnement bag Ukraine-interventionerne bør snarere forstås som arven fra Andropov og Sovjettiden.

Snegovaya (2015: 13) påpeger, at selve antagelsen om, at Ukraine-interventionerne er udtryk for en ny, kohærent strategi »over-exaggerates Russia's actual capacities and inflates its image to the point of perceived invincibility". Med andre ord skaber den hyppige, endog uforsigtige, brug af hybridkrigskrigsbegrebet et forvrænget billede af Ruslands egentlige kapabiliteter. Som interventionerne i Donbas i sig selv er et billede på, er de russiske efterretningstjenester absolut fejlbarlige og formår langtfra altid at agere som en enhedsaktør.

\section{Sammenfattende konklusion}

Konceptet hybridkrig har klare begrænsninger, når det kommer til at belyse Ruslands udenrigspolitiske kurs, motiver og militære kapabiliteter, og jeg har peget på efterretningsteorien som alternativ analyseramme. Herved kortlægges kontinuiteten i Ruslands ageren, og denne kontinuitets ophav, der kan spores tilbage til efterretningstjenesternes særegne, strategiske kultur, og den indflydelse, sikkerhedsapparatet har fastholdt gennem Sovjettiden og frem til i dag. En analyse af russisk krigsførelse, herunder Ukraine-interventionerne, bør derfor foretages med efterretningstjenesterne som det afgørende omdrejningspunkt. Et efterretningsteoretisk perspektiv gør det muligt at specificere, hvilke anskuelser og antagelser, russisk strategisk tænkning er baseret på, hvorfor det samtidig bliver muligt at komme med et forsigtigt bud på, hvad Vesten kan forvente fra Kreml. Dette er omvendt ikke muligt med hybridkrigsbegrebet som analyseværktøj, da dette indebærer en risiko for at overvurdere »det nye " i Ruslands krigsførelse, blandt andet fordi der ikke fokuseres på det historiske og værdimæssige ophav - forankret i efterretningstjenesterne - og kontinuiteten heri.

Efterretningstjenesternes krigsmentalitet er centreret omkring en stræben efter regimesikkerhed, og består af tre grundkomponenter: en nulsumstankegang, en opfattelse af truslen fra Vesten som overhængende samt, at handling trumfer passivitet (Galeotti 2016). Jeg har illustreret, hvorledes de russiske politiske beslutningstageres ageren udspringer af efterretningstjenesternes strategiske tænkning, som er styrende i forholdet til Vesten. I praksis udmønter dette sig som en gennemgående frygt, der i dag kommer til udtryk i Kremls nuværende farverevolutions-narrativ, hvor store dele af verdens ustabilitet tolkes som et produkt af vestlige landets aktive foranstaltninger. I tillæg hertil har analysen kortlagt, hvordan krigen i Ukraine fra russisk side konkret opfattes og håndteres netop som en efterretningskrig; en krig, der i stor stil udkæmpes af efterretningstjenesterne, og på deres præmisser.

Med hybridkrigsbegrebet som udgangspunkt for at forstå russisk udenrigspolitik synes det nærliggende at hævde, at Rusland agerer på baggrund af en gennemført, kohærent (og ny) militærstrategi. Min efterretningsteoretiske analyse har omvendt illustreret, hvordan ideen om, at truslen fra Vesten er overhængende, er central for Ruslands udenrigspolitiske adfærd, der således er baseret på frygt snarere end en følelse af overlegenhed. 
Det blev herigennem yderligere klart, at indenrigspolitiske faktorer og interne magtrelationer spiller en central rolle for Ruslands aktiviteter i Ukraine, hvilket leder til inddragelsen af den liberale efterretningsteoretiske model. Ved hermed at bevæge mig ud over forestillingen om efterretningstjenesterne som en enhedsaktør har jeg illustreret, at Ukraine-interventionerne nødvendigvis må forstås på baggrund af disses interne rivalisering. I særdeleshed denne interne dimension har været overset i klassiske udlægninger af Ukraine-interventionerne. Samlet set udgør sikkerhedsapparatet en aktør, der er styret af frygt udadtil, og som samtidig er præget af intern splittelse. Vestlige landes beslutningstagere samt vestlige analytikere bør derfor være varsomme med at tolke Ruslands vilje til med magt at gribe ind i Ukraine samt de anvendte metoder som tegn på, at landets militære og ikke-militære kapabiliteter er styrkede. Vesten må fortsat forvente et »lunefuldt« Rusland, der handler på baggrund af undertiden modstridende interesser.

\section{Litteratur}

Andrew, Christopher \& Vasili Mitrokhin (2000) The Mitrokhin Archive: The KGB in Europe and the West. London: The Penguin Press.

Bateman, Aaron (2014) »The Political Influence of the Russian Security Services«. The fournal of Slavic Military Studies 27 (3): 380-403.

Betts, Richard K. (1978) "Analysis, War and Decision: Why Intelligence Failures are Inevitable». World Politics 31 (2): 61-89.

Blank, Stephen (2012) »Perspectives on Russian Foreign Policy«. U.S. Army War College Strategic Studies Institute. Tilgængelig på: http://ssi.armywarcollege.edu/pdffiles/pub1115.pdf. Læsedato 2. september 2017.

Bouchet, Nicolas (2016) "Russia's Militarization of Color Revolutions». Policy Perspectives, Center for Security Studies ETH Zürich (4) 2: 1-4.

Bukkvoll, Tor (2016) "Russian Special Operations Forces in Crimea and Donbas». U.S. Army War College Strategic Studies Institute. Tilgængelig på: http://ssi.armywarcollege.edu/pubs/parameters/issues/Summer_2016/5_Bukkvoll.pdf. Læsedato 2. september 2017.

Cordesman, Anthony H. (2014) »Russia and the 'Color Revolution'. A Russian Military View of a World Destabilized by the US and the West«. Center for Strategic \& International Studies. Tilgængelig på: https://www.csis.org/analysis/russia-and-\%E2\%80\%9Ccolor-revolution \%E2\%80\%9D. Læsedato 30. august 2017.

Dreyfuss, Bob (2014) „Full Text and Analysis of Putin’s Crimea Speech». The Nation 19. marts. Tilgængelig på: https://www.thenation.com/article/full-text-and-analysis-putins-crimea-speech/. Læsedato 30. august 2017.

Freedman, Lawrence (2015) „Ukraine and the Art of Exhaustion«. War on the Rocks. Tilgængelig på: http:// warontherocks.com/2015/08/ukraine-and-the-art-of-exhaustion/. Læsedato 1. september 2017.

Galeotti, Mark (2014a) "The Gerasimov Doctrine and Russian Non-Linear War». In Moscow's Shadows. Tilgængelig på: https://inmoscowsshadows.wordpress.com/2014/07/06/the-gerasimov-doctrine-andrussian-nonlinear-war/. Læsedato 2. september 2017.

Galeotti, Mark (2014b) »Ukraine: a Perversely Good War for the GRU«. In Moscow’s Shadows. Tilgængelig på: https:/inmoscowsshadows.wordpress.com/2014/05/01/ukraine-a-perversely-good-war-for-the-gru/.

Galeotti, Mark (2015) »'Hybrid War' and 'Little Green Men': How It Works and How It Doesn't«. E-International Relations. Tilgængelig på: http:/www.e-ir.info/2015/04/16/hybrid-war-and-little-green-men-how-itworks-and-how-it-doesnt/. Læsedato 2. september 2017.

Galeotti, Mark (2016) „Putin’s Hydra: Inside Russia’s Intelligence Services«. European Council on Foreign Relations. Tilgængelig på: http://www.ecfr.eu/publications/summary/putins_hydra_inside_russias_intelligence_services Læsedato 3. september 2017.

Giles, Keir (2016) "Russia's 'New’Tools for Confronting the West: Continuity and Innovation in Moscow's Exercise of Power». Chatham House, Royal Institute of International Affairs: Russia and Eurasia Programme. 


\section{SIMONE GUNDTOFT SIMONSEN}

Tilgængelig på: https:/www.chathamhouse.org/publication/russias-new-tools-confronting-west. Læsedato 3. september 2017.

Gourevitch, Peter (1978) "The Second Image Reversed:The International Sources of Domestic Politics«. International Organization 32 (4): 881-912.

Hansen, Flemming Splidsboel (2016) »Russisk Hybridkrig: Fremtidens krig er i fuld gang«. Dansk Institut for Internationale Studier (DIIS). Tilgængelig på: http://pure.diis.dk/ws/files/447424/DIIS_PB_Russisk_Hybridkrig_2016_web.pdf. Læsedato 3. september 2017.

Hoffman, Frank G. (2007) Conflict in the 21th Century: the Rise of Hybrid Wars. Arlington VA, USA: Potomac Institute Press.

Kaldor, Mary (1999) New E OldWars: OrganizedViolence in a Global Era. Cambridge, U.K.: Polity Press.

Korsunskaya, Darya (2014) »Putin says Russia must prevent 'color revolution' «. Reuters 20. november. Tilgængelig på: http://www.reuters.com/article/us-russia-putin-security-idUSKCN0J41J620141120. Læsedato 3. september 2017.

Kulavig, Erik (2007) KGB - De russiske sikkerhedstjenester fra Ivan den Grusomme til Vladimir Putin. København: Aschehoug Dansk Forlag.

McDermott, Roger N. (2016) »Learning From Today’s Wars: Does Russia Have a Gerasimov Doctrine?«. The U.S. Army War College Strategic Studies Institute. Tilgængelig på: https://pdfs.semanticscholar.org/f9e8/3 0894f4e5f758d946bbddee0850e9ac4e86f.pdf. Læsedato 3. september 2017.

Office of the United Nations High Commissioner for Human Rights (OHCHR) (2017) »Report on the human rights situation in Ukraine 16 February to 15 Maj 2017 «Tilgængelig på: http://reliefweb.int/sites/reliefweb. int/files/resources/UAReport18th_EN.pdf. Læsedato 3. september 2017.

Patrusjev, Nikolaj (2015) "Sa destabilisatsijej Ukrainy skryvajetsja popytka radikalnogo oslablenija Rossii« Kommersant 22. juni. Tilgængelig på: https://www.kommersant.ru/doc/2752250. Læsedato 3. september 2017.

Poulsen, Niels Bo (2014) "The Past as Strategy - Russia and its use of history in the Ukraine conflict". Royal Danish Defence College 02 (02): 2-6.

Pringle, Robert W. (2000) "Andropov's Counterintelligence state«. International fournal of Intelligence and Counterintelligence 13 (2): 193-203.

Pringle, Robert W. (2001) »PutIn: The New Andropov?«. International fournal of Intelligence and Counterintelligence 14 (4): 545-558.

Putin, Vladimir Vladimirovitj (2014a) „Obrasjtjenije Presidenta Rossijskoj Federatsii».Tilgængelig på: http:// www.kremlin.ru/events/president/news/20603. Læsedato 3. september 2017.

Putin, Vladimir Vladimirovitj (2014b) »Sasedanije Mesjdunarodnogo diskussionnogo kluba Valdaj«. Tilgængelig på: http://kremlin.ru/events/president/news/46860\#sel=72:1:FcC,72:92:UhC. Læsedato 3. september 2017.

Reichborn-Kjennerud, Erik \& Patrick Cullen (2016) "What is Hybrid Warfare?«. NUPI Policy Brief 1/2016. Tilgængelig på: https://brage.bibsys.no/xmlui/bitstream/id/411369/NUPI_Policy_Brief_1_Reichborn_Kjennerud_Cullen.pdf. Læsedato 3. september 2017.

Renz, Bettina \& Hanna Smith (2016)»Russia and Hybrid Warfare - Going Beyond the Label«. Aleksanteri Institute, University of Finland. Tilgængelig på: http://www.stratcomcoe.org/bettina-renz-and-hanna-smithrussia-and-hybrid-warfare-going-beyond-label. Læsedato 3. september 2017.

Richards, Julian (2010) The Art and Science of Intelligence Analysis. Oxford: Oxford University Press.

RUSI (2015) »Briefing Paper: Russian Forces in Ukraine«. Tilgængelig på: https://rusi.org/publication/briefingpapers/russian-forces-ukraine. Læsedato 30. august 2017.

Sherr, James (2013) Hard Diplomacy and Soft Coercion: Russia's Influence Abroad. Chatham House Royal Institute of International Affairs. London: Latimer.

Skak, Mette (2015) "Ruslands betændte forhold til USA«. Dansk Selskab for Statskundskab. Tilgængelig på: http://dpsa.dk/papers/Mette\%20Skak(2015)\%20Russia-USA\%20ANTAGONISM\%20(dansk\%20 manus).pdf. Læsedato 30. august 2017.

Skak, Mette (2016) "Russian Strategic Culture: The Role of Today’s Chekisty». Contemporary Politics 22 (3): 324-341.

Snegovaya, Maria (2015) „Putin's Information Warfare in Ukraine: Soviet Origins of Russia's Hybrid Warfare", Understanding War. Tilgængelig på: http://www.understandingwar.org/report/putins-informationwarfare-ukraine-soviet-origins-russias-hybrid-warfare. Læsedato 3. september 2017.

Soldatov, Andrei \& Irina Borogan (2010a) "Russia's New Nobility. The Rise of the Security Services in Putin's Kremlin«. Foreign Affairs ESSAY September/October. Tilgængelig på: https://www.foreignaffairs.com/ articles/russia-fsu/2010-09-01/russias-new-nobility. Læsedato 30. august 2017.

Soldatov. Andrei \& Irina Borogan (2010b) The Restoration of Russia's Security State and the Enduring Legacy of the KGB. New York: Public Affairs. 
Stempel, John D. (2007) "Covert Action and Diplomacy«. International fournal of Intelligence and Counterintelligence 20 (1): 122-135.

Strategija Natsionalnoj Besopasnosti (2015) "O Strategii natsionalnoj besopasnosti Rossijskoj Federatsii«. Tilgængelig på http://kremlin.ru/acts/bank/40391. Læsedato 30. august 2017.

Taylor, Brian D. (2011) State Building in Putin's Russia: Policing and Coercion after Communism. Cambridge, New York: Cambridge University Press.

Taylor, Stan A. (2010) "The Role of Intelligence in National Security" i Alan Collins (red.) Contemporary Security Studies. Oxford: Oxford University Press (299-319).

\section{Bilag 1: Oversigt over forkortelser}

FSB: Føderale Sikkerhedstjeneste - Federalnaja Slusjba Besopasnosti

FSO: Føderale Beskyttelsestjeneste - Federalnaja Slusjba Okhrany

GPU: Statslige Politiske Hovedforvaltning - Gosudarstvennoje Polititjeskoje Upravlenije

GRU: Øverste Efterretningsdirektorat - Glavnoje Rasvedyvatelnoje Upravlenije

KGB: Komiteen for Statslig Sikkerhed - Komitet Gosudarstvennoj Besopasnosti

NKVD: Folkekommissariatet for Indre Anliggender - Narodnyj Komissariat Vnutrennikh Del

SVR: Udenrigsefterretningstjenesten - Slusjba Vnesjnej Rasvedki 